\title{
Evaluation of hematological parameters of patients with profound unilateral and mild to profound bilateral sensorineural hearing loss
}

\author{
Tek taraflı total ve iki taraflı hafif ila çok ileri derecede sensörinöral işitme kaybı olan \\ hastalarn hematolojik parametrelerinin değerlendirilmesi
}

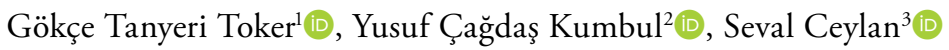

\begin{abstract}
${ }^{1}$ Department of Otolaryngology, Izmir Katip Çelebi University, Atatürk Training and Research Hospital, Izmir, Turkey
${ }^{2}$ Department of Otolaryngology, Süleyman Demirel University Faculty of Medicine, Isparta, Turkey

${ }^{3}$ Division of Audiology, Izmir Katip Çelebi University, Atatürk Training and Research Hospital, Izmir, Turkey
\end{abstract}

\begin{abstract}
Objectives: This study aimed to investigate whether changes in blood cells have an effect on sensorineural hearing loss (SNHL) and compare the hematological parameters of profound unilateral and mild to profound bilateral SNHL patients and the normal population.

Patients and Methods: This retrospective study included 100 SNHL patients ( 81 males, 19 females; mean age: $37.8 \pm 16.8$ years; range, 18 to 83 years) and 32 healthy volunteers ( 22 males, 10 females; mean age: $32.8 \pm 5.7$ years; range 22 to 46 years) between January 2018 and February 2019. Patients who underwent pure tone audiometry and auditory brainstem response (ABR) tests for any reason and were found to have SNHL with no accompanying disease, and those that are non-smokers and without medication were included. Hematological parameters were evaluated in all three groups.

Results: Of the 100 SNHL patients, 59 had bilateral and 41 had profound unilateral SNHL. Among the evaluated hematological parameters, the difference in red blood cell count, hematocrit, hemoglobin, platelet distribution width, and neutrophil to lymphocyte ratio (NLR) between the groups was statistically significant $(\mathrm{p}<0.001)$.
\end{abstract}

Conclusion: Erythrocyte values were high in patients with profound unilateral SNHL, whereas platelet-related values [platelet count, PDW, and platelet to lymphocyte ratio) were higher in patients with bilateral SNHL. In addition, the NLR was found to be high in these patient groups. These findings may provide a treatment target, particularly for profound unilateral SNHL, and may shed light on further studies on SNHL.

Keywords: Bilateral, complete blood count, hematological parameters, neutrophil to lymphocyte ratio, sensorineural hearing loss, unilateral.

\section{$\ddot{O} Z$}

Amaç: Bu çalışmada kan hücrelerindeki değişikliklerin sensörinöral işitme kaybı (SNİK) üzerinde bir etkisi olup olmadığı araştırıldı ve tek taraflı total ve hafif ila derin iki taraflı SNIK'li hastalar ile normal nüfusun hematolojik parametreleri karşılaştırıldı.

Hastalar ve Yöntemler: January 2018 - February 2019 tarihleri arasında yapılan bu çalışmaya 100 SNİK'li hasta (81 erkek, 19 kadın; ort. yaş: $37.8 \pm 16.8$ yıl; dağılım $18-83$ yıl) ve 32 sağlıklı gönüllü (22 erkek, 10 kadın; ort. yaş: $32.8 \pm 5.7$ yıl; dağılım 22-46 yıl) dahil edildi. Hasta grubuna herhangi bir nedenle saf ses odyometri ile ABR (auditory brainstem response) testi yapılan ve SNIK saptanan, ek hastalığı, ilaç ve sigara kullanımı olmayanlar dahil edildi. Her üç grupta da hematolojik parametreler değerlendirildi.

Bulgular: Sensörinöral işitme kaybı olan 100 hastadan 59'unda iki taraflı, 41'inde total tek taraflı SNIK saptandı. Değerlendirilen hematolojik parametreler arasında eritrosit sayımı, hematokrit, hemoglobin, platelet dağılım genişliği (PDW) ve nötrofil-lenfosit oranı (NLR) değerlerinde gruplar arasındaki fark istatistiksel olarak anlamlı bulundu $(\mathrm{p}<0.001)$.

Sonuç: Tek taraflı total SNIK'li hastalarda eritrosit değerleri yüksek bulunurken, iki taraflı SNIK'li hastalarda trombosit ilişkili değerler (trombosit sayımı, PDW ve trombosit lenfosit oranı) daha yüksek bulundu. Ayrıca NLR bu hasta gruplarında yüksek bulundu. Bu bulgular özellikle tek taraflı total SNIK için tedavi hedefi sağlayabilir ve gelecekteki SNIK çalışmalarına ışık tutabilir.

Anahtar sözcükler: İki taraflı, tam kan sayımı, hematolojik parametreler, nötrofil-lenfosit oranı, sensörinöral işitme kaybı, tek taraflı.

Received: April 30, 2021 Accepted: June 14, 2021 Published online: November 05, 2021

Correspondence: Gökçe Tanyeri Toker, MD. İzmir Katip Çelebi Üniversitesi, Atatürk Eğitim ve Araştırma Hastanesi Kulak Burun Boğaz Kliniği, 35150 Karabağlar, İzmir, Turkey. e-mail: gokce.tanyeri@gmail.com

\section{Citation:}

Tanyeri Toker G, Kumbul YÇ, Ceylan S. Evaluation of hematological parameters of patients with profound unilateral and mild to profound bilateral sensorineural hearing loss. KBB Uygulamaları 2021;9(3):87-92. 
Sensorineural hearing loss (SNHL) occurs as a result of damage to the hair cells in the inner ear, the vestibulocochlear nerve, or the brain's central processing centers. ${ }^{[1]}$ This type of hearing loss (HL) includes congenital-syndromic, age- and noise-related HL, head injury, Meniere's disease, ototoxic drugs, vestibular schwannoma, autoimmune, barotrauma, and perilymphatic fistulas. Additionally, it can be seen in some systematic diseases, including meningitis, measles, and diabetes. It is difficult to anticipate and prevent as patients generally consult a doctor after the HL occurs, which is almost always permanent.

The neutrophil to lymphocyte ratio (NLR) and the platelet to lymphocyte ratio (PLR) can be easily calculated from a complete blood count (CBC). These values have been evaluated in terms of their predictive and prognostic value in sudden SNHL in many studies, and statistically significant results have been obtained in most of them. ${ }^{[2-4]}$ However, no studies have evaluated NLR, PLR, and other hematological parameters in profound unilateral or mild to profound bilateral SNHL. Therefore, both NLR and PLR, and other hematological parameters [white blood cell (WBC) count, red blood cell (RBC) count, hematocrit $(\mathrm{Htc})$, hemoglobin $(\mathrm{Hb})$, platelet (PLT) count, platelet distribution width (PDW), mean platelet volume (MPV), and mean corpuscular volume $(\mathrm{MCV})]$ were compared in patients with profound unilateral and mild to profound bilateral SNHL in this study to investigate whether changes in blood cells have an effect on the type of SNHL. These patient groups were also compared to healthy volunteers.

\section{PATIENTS AND METHODS}

This retrospective study was conducted at Izmir Katip Celebi University Ataturk Training and Research Hospital Department of Otolaryngology between January 2018 and February 2019. The study included a total of 100 patients $(81$ males, 19 females; mean age: $37.8 \pm 16.8$ years; range, 18 to 83 years) and 32 healthy volunteers (22 males, 10 females; mean age: $32.8 \pm 5.7$ years; range 22 to 46 years). The patient group included individuals who were diagnosed with profound unilateral or mild to profound bilateral SNHL along with other individuals who were confirmed to have SNHL with a pure tone audiometry (PTA) and auditory brainstem response (ABR) test due to changes in or the inability to determine their hearing thresholds or where confirmation of PTA was required. Among the individuals who had the PTA test, those with normal limits $(\leq 20 \mathrm{~dB} \mathrm{HL})$ were included in the control group. Subjects only over the age of 18 were included in the study. A systemic physical examination, a detailed otological examination, hematological and biochemical studies, and audiological evaluation were performed on all patients. Data were obtained from patient files and then analyzed. Profound unilateral SNHL patients with hearing thresholds of $<25 \mathrm{~dB} \mathrm{nHL}$ on their better-hearing side and $\geq 90 \mathrm{~dB} \mathrm{nHL}$ on their poorer-hearing side, and mild to profound bilateral SNHL patients whose hearing thresholds were $>25 \mathrm{~dB}$ nHL on both sides in the ABR test were included in the study. Patients with a history of neuro-otological diseases, vestibular disorders, systemic diseases, acute infections, sudden SNHL, conductive HL, or HL due to smoking or drug use were excluded. The study protocol was approved by the Izmir Katip Celebi University Atatürk Training and Research Hospital Non-Invasive Local Ethics Committee (Ethics Committee No: 27.03.2019-117). The study was conducted in accordance with the principles of the Declaration of Helsinki.

The individuals were allowed to lie on a bed in the test room in a comfortable position for their ABR test. For sedation, patients were given an appropriate dose of midazolam (Dormicum ${ }^{\circledR}$, Roche, Turkey) by the anesthesiologist. A pulse oximeter device (Contec ${ }^{\circledR}$ CMS-60, China) was used to control patients' pulse and oxygenation after sedation. A $10 \mathrm{~L}, 150$ bar, $1.5 \mathrm{~m}^{3}$ medical oxygen tube was kept in the test room to provide oxygen to the patients when necessary. The ABR recordings were performed using the Interacoustic Eclipse Ep $25 \mathrm{ABR}$ system (Interacoustics A/S, Denmark). The positive (active) electrode was placed along the upper midline $(\mathrm{Fz})$ of the forehead, the ground electrode (ground) along the lower part of the midline (Fpz), and the reference electrodes on the right (M2) and left (M1) mastoids. Care was taken to ensure that the electrode-skin impedance was below $3 \mathrm{k} \Omega$ and that the cables did not overlap. The click stimulus was sent through the ER-3A insert (Etymotic Research) headphones in alternating polarity at a rate of 20.1. In the measurements, the high-pass filter (HPF) was $100 \mathrm{~Hz}$, the low-pass filter (LPF) was $3,000 \mathrm{~Hz}$, and the artifact rejection level was set at $40 \mathrm{nV}$. Ears with total HL were tested at sound intensities of $100 \mathrm{~dB}$ and $95 \mathrm{~dB}$. During the testing of ears with total HL, a mask sound was sent to the hearing ears.

Since the ABR test was performed with sedation in our routine practice, the patients were evaluated by an anesthesiologist before the test, and the parameters of the $\mathrm{CBC}$, one of the routine tests performed during the anesthesia examination, were compared. 
These parameters were WBC, RBC, Htc, Hb, NLR, PLT, PLR, MPV, PDW, and MCV. All patients who had fasted for $8 \mathrm{~h}$ and whose CBC tests were performed between 6 a.m. and 10 a.m. were enrolled.

\section{Statistical analysis}

Statistical analyses were performed using IBM SPSS version 23.0 software (IBM Corp., Armonk, NY, USA). Descriptive findings are presented as number, percentage, and mean \pm standard deviation (SD). The difference between sexes and the ears was analyzed by the Student's t-test or the Mann-Whitney U test according to their distribution. The differences between the mean age and the hematological parameters of the bilateral, unilateral, and control groups were compared using the one-way ANOVA test. In the one-way ANOVA analysis, the homogeneity of variances was evaluated by Levene's test. Statistical significance was accepted at $p<0.05$. If there was a significant difference between the groups, post-hoc analyses were performed with Dunnett T3 test. Since post-hoc comparisons between the three groups were conducted, the statistical significance was accepted at $\mathrm{p}<0.017$.

\section{RESULTS}

In the study, it was found that 59 of the patients had mild to profound bilateral SNHL and 41 had profound unilateral SNHL. Twenty-six profound unilateral SNHL patients had a HL on the right side, and 15 had a HL on the left side. There was profound unilateral SNHL in five (26.3\%) female patients and

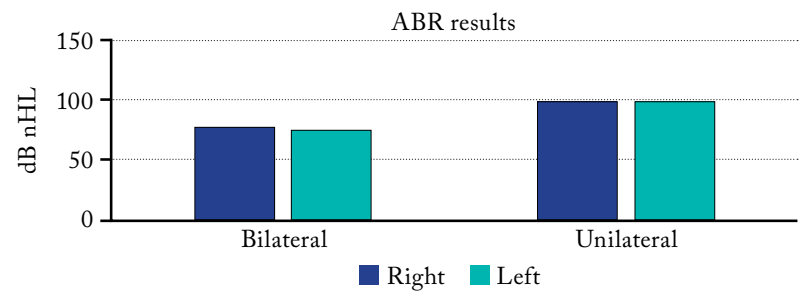

Figure 1. Mean values of $\mathrm{ABR}$ results in patient groups (in the profound unilateral group, the averages of the side with hearing loss are presented separately).

ABR: Auditory brainstem response; dB: Decibel; nHL: Normalized hearing level.

36 (44.4\%) male patients, and bilateral SNHL was detected in 14 (73.7\%) female patients and 45 (55.6\%) male patients. The mean values of ABR results are given in Figure 1. The mean age of the profound unilateral SNHL patients was $28.5 \pm 10.5$ years, and the mean age of the bilateral SNHL patients was $44.4 \pm 17.3$ years. While the difference between the sexes was not statisticaly significant $(p=0.148)$, the difference between the patient groups in terms of age was significant $(\mathrm{p}<0.001)$.

The difference between the patient groups and the control group in age, $\mathrm{RBC}$, Htc, and $\mathrm{Hb}$ values was significant, while the difference between the control group and the profound unilateral SNHL group was not significant. As for the PDW and NLR values, only the difference between the control group and the patient groups was found to be significant, but a statistically

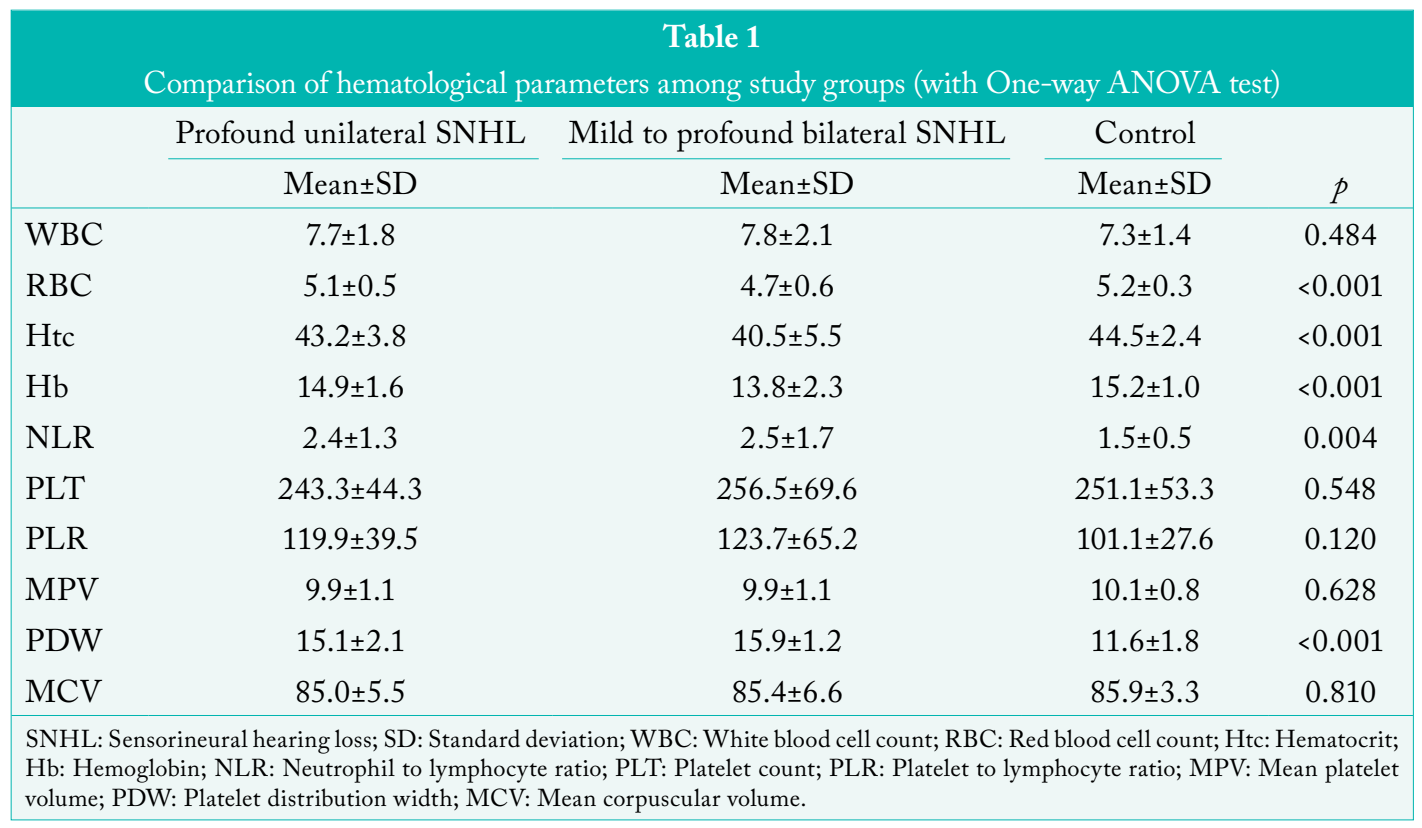




Table 2
Comparison of statistically significant variables among groups in pairs with the
One-way ANOVA test

significant difference was not found when the patient groups were compared with each other. A comparison of the hematological parameters between groups is provided in Tables 1 and 2.

\section{DISCUSSION}

In this study, patients with profound unilateral and mild to profound bilateral SNHL, whose diagnosis was confirmed by ABR, were compared to the healthy control group. Our study showed that the difference between patient groups in age and $\mathrm{RBC}, \mathrm{Htc}$, and $\mathrm{Hb}$ values was significant. In addition, the difference between the control group and the patient group in terms of PDW and NLR values was significant.

Sensorineural HL is caused by damage to the structures in the inner ear, the vestibulocochlear nerve, or the brain's central processing centers. It is the cause of more than $90 \%$ of HL in adults. Sensorineural HL can occur in one or both ears, depending on the cause. ${ }^{[1]}$

Although unilateral SNHL has not been considered an important health problem in the past, it is generally accepted as a moderate to severe disability in recent studies. These patients cannot benefit from sound localization that binaural hearing provides, sound amplification from binaural summation, and the noise masking effect of the brain. Therefore, patients generally present with complaints of not being able to determine the direction of the sound and perceive sounds in noisy environments.

In our study, patients were selected from those who underwent ABR testing. The terms "non-organic HL," "functional HL," and "pseudohypacusis" are used to describe people who embellish or fake HL for financial or personal gain, despite presenting no pathology in the hearing system. ${ }^{[5]}$ The ABR test is used in the objective evaluation of HL and in distinguishing organic HL from non-organic HL. ${ }^{[6]}$ Therefore, patients whose diagnosis of SNHL was clarified with the ABR test were included in our study.

There are few studies in the literature evaluating the hematological parameters of patients with SNHL, and almost all of them are studies conducted in patients with sudden SNHL. White blood cell count, RBC, $\mathrm{Htc}, \mathrm{Hb}, \mathrm{NLR}, \mathrm{PLT}$, PLR, MPV, PDW, and MCV are parameters that can easily be evaluated in routine CBC tests. These are convenient indicators in terms of cost and accessibility. There are studies that have become very popular examining the use of NLR, PLR, $\mathrm{RDW}$, and MCV in otorhinolaryngology clinics and 
many other clinics. $\mathrm{Ni}$ et al..$^{[7]}$ determined that chronic inflammation causes sudden SNHL and that NLR and PLR values are higher in the non-healing group than in the healing group. There are many studies of sudden SNHL with similar results to the data of this study. ${ }^{[2,3,7-11]}$ However, a study evaluating hematological parameters in profound unilateral or bilateral SNHL has not been conducted to our knowledge.

Bozan et al. ${ }^{[12]}$ evaluated the high frequency $\mathrm{HL}$ seen in ankylosing spondylitis (AS) and examined the changes in MPV, PLR, RDW, and NLR values. Although they found significant changes in these values, they eventually associated these changes with AS. It has been emphasized that high-frequency SNHL is also common in patients with AS and may include an extra-articular feature of the disease. Thirty patients and 35 healthy volunteers were included in this study. In our study, these values were evaluated on 100 patients with no known systemic disease. In another study, Przewoźny et al. ${ }^{[13]}$ found that decreased RBC, PLT, and Htc values has a negative and statistically significant influence on HL. However, HL was evaluated in 44 patients with ischemic stroke, including sudden SNHL in four patients, bilateral SNHL in 33 patients, and unilateral SNHL in 11 patients. A $10 \%$ decrease in RBC, $1.6 \%$ decrease in PLT and 15\% decrease in Htc were reported. Although a comparison was made with 16 patients with ischemic stroke with normal hearing, it was observed that many risk factors (smoking, alcohol, heart disease, hypertension, diabetes, etc.) that could affect hearing were present in these patients. In addition, this study differs from our study due to the number of patients and heterogeneity in the patient group. In this sense, our study is the first study to the best of our current knowledge in which hematological parameters in SNHL were evaluated in a sufficient number of patients.

In a study of 1,897 participants, Abe et al. ${ }^{[14]}$ investigated the correlation between PLT and the development of hearing impairment over a five-year period. They found that a low to normal PLT correlates with a low-frequency hearing impairment, and a decreasing PLT in low to normal platelet subjects is an independent risk factor. However, this study has several limitations such as evaluation of only two frequencies $(1,000$ and $4,000 \mathrm{~Hz})$ and air conduction, insufficient knowledge on ear examinations, not excluding systemic or ear diseases, and including smokers or individuals on medications, particularly ototoxic medications. In addition, although the MPV and PDW may be more related to hearing impairment than PLT, as the authors stated, only PLTs were evaluated in this study. In the present study, none of the patients had an additional systemic or ear disease, drug use, and smoking habit, and the tympanic membranes of all the patients were normal. Since systemic diseases, drug use, and smoking may affect hearing and cause changes in hematological parameters, it is critical to include these conditions in the exclusion criteria in studies evaluating these parameters, as in our study.

In this study, hematological parameters were evaluated, but biochemical values were not evaluated. There are also biochemical parameters evaluated in SNHL in the literature. Gangopaninyay et al. ${ }^{[15]}$ evaluated glucose levels from biochemical parameters and determined that 14 of 75 patients with unilateral SNHL had hyperglycemia. It has been stated that the increase in blood sugar levels after meals in diabetic patients may be a risk factor for cochlear dysfunction. There are also studies linking iron levels and total bilirubin values with SNHL. ${ }^{[16,17]}$ In our study, the RBC, Htc, and $\mathrm{Hb}$ values were found to be significant. There was no difference between the patient groups regarding the NLR (generally high in patients with sudden SNHL) and the PDW. However, the difference between the control group and the patient group was statistically significant. While the values of erythrocytes were found to be high in patients with profound unilateral SNHL, the platelet-related values (PLT, PDW, and PLR) were higher in patients with bilateral SNHL, although there was no statistically significant difference between the two groups.

Among the hematological parameters, the most emphasized and studied parameters are NLR and PLR. Neutrophil to lymphocyte ratio and PLR show the ratio of two different WBC subtypes and are considered more stable than single inflammatory parameters. ${ }^{[2]}$ Neutrophil to lymphocyte ratio has been reported to be more valuable than any other parameter of single-cell counts in predicting the onset and development of sudden SNHL, as in many other diseases such as cancer and heart diseases. Neutrophil to lymphocyte ratio is a widely available biomarker of inflammation that can be easily measured routinely in CBCs without any additional cost. It is related to the clinical situation and can aid in the risk stratification of patients with various diseases. It has also been reported to be as valuable as some high-cost inflammatory markers such as interleukin (IL)-6, IL-1a, IL-8, and tumor necrosis factor-(TNF- $\alpha)^{\left[{ }^{[2]}\right.}$ The NLR, which was found to be high in sudden SNHL in the literature, was higher in the patient groups than in the control group in this study. This shows that the NLR value increases in SNHL in general and not only in the sudden occurrence of SNHL. ${ }^{[8]}$ Therefore, a high NLR may give an idea 
for the development of SNHL; however, this may raise questions on its value in sudden SNHL.

Unfortunately, these laboratory parameters may have shortcomings due to variables such as age and sex. While there were no differences according to sex observed in our study, finding a difference in terms of age may limit the reliability of these parameters. Further studies including different age groups are needed on this subject. This study has another limitation. Patients with mild to profound SNHL were evaluated together in the bilateral patient group. This is due to the inability to obtain sufficient numbers for statistical analysis when separately evaluated. However, it is difficult to find patients of the same age who have undergone ABR and do not have any disease or drug use. In addition, it would be more valuable to investigate whether the parameters that were found to be significant in this study can be utilized as predictive and prognostic factors.

In conclusion, the profound unilateral SNHL group had high values of erythrocyte-related parameters, and the mild to profound bilateral SNHL group had high values of platelet-related parameters in this study. In addition, the NLR was found to be high in these patient groups. These findings may provide a treatment target, particularly for profound unilateral SNHL, and shed light on different studies on SNHL.

\section{Declaration of conflicting interests}

The authors declared no conflicts of interest with respect to the authorship and/or publication of this article.

\section{Funding}

The authors received no financial support for the research and/or authorship of this article.

\section{REFERENCES}

1. Tanna RJ, Lin JW, De Jesus O. Sensorineural Hearing Loss. 2021 Jul 26. In: StatPearls [Internet]. Treasure Island (FL): StatPearls Publishing; 2021 Jan-. PMID: 33351419.

2. Chen L, Zhang G, Zhang Z, Wang Y, Hu L, Wu J. Neutrophil-to-lymphocyte ratio predicts diagnosis and prognosis of idiopathic sudden sensorineural hearing loss: A systematic review and meta-analysis. Medicine (Baltimore) 2018;97:e12492.

3. Cao Z, Li Z, Xiang H, Huang S, Gao J, Zhan X, et al. Prognostic role of haematological indices in sudden sensorineural hearing loss: Review and meta-analysis. Clin Chim Acta 2018;483:104-11.
4. Seo YJ, Park YA, Bong JP, Park DJ, Park SY. Predictive value of neutrophil to lymphocyte ratio in first-time and recurrent idiopathic sudden sensorineural hearing loss. Auris Nasus Larynx 2015;42:438-42.

5. Martin FN, Clarck G. Nonorganic Hearing loss. In: Katz J, editor. Handbook of Clinical Audiology. 7th ed. Philadelphia: Wolters Kluwer Health; 2015. p. 617-9.

6. Hall JW. ABR Adult Disease and Disorders and Clinical Applications. In: Dragin SD, editor. New handbook of Auditory Evoked Responses. 1st ed. Boston: Pearson; 2007. p. 370.

7. Ni W, Song SP, Jiang YD. Association between routine hematological parameters and sudden sensorineural hearing loss: A meta-analysis. J Otol 2021;16:47-54.

8. Qiao XF, Li X, Wang GP, Bai YH, Zheng W, Li TL. Neutrophil-to-lymphocyte ratio and platelet-to-lymphocyte ratio in patients with sudden sensorineural hearing loss. Med Princ Pract 2019;28:23-7.

9. Ha R, Lim BW, Kim DH, Park JW, Cho CH, Lee JH. Predictive values of neutrophil to lymphocyte ratio (NLR), platelet to lymphocyte ratio (PLR), and other prognostic factors in pediatric idiopathic sudden sensorineural hearing loss. Int J Pediatr Otorhinolaryngol 2019;120:134-9.

10. Xie W, Dai Q, Liu J, Liu Y, Hellström S, Duan M. Analysis of clinical and laboratory findings of idiopathic sudden sensorineural hearing loss. Sci Rep 2020;10:6057.

11. Salvago P, Rizzo S, Bianco A, Martines F. Sudden sensorineural hearing loss: Is there a relationship between routine haematological parameters and audiogram shapes? Int J Audiol 2017;56:148-53.

12. Bozan N, Alpayci M, Aslan M, Cankaya H, Kiroglu AF, Turan M, et al. Mean platelet volume, red cell distribution width, platelet-to-lymphocyte and neutrophil-to-lymphocyte ratios in patients with ankylosing spondylitis and their relationships with high-frequency hearing thresholds. Eur Arch Otorhinolaryngol 2016;273:3663-72.

13. Przewoźny T, Gasecki D, Narozny W, Nyka W. Risk factors of sensorineural hearing loss in patients with ischemic stroke. Otol Neurotol 2008;29:745-50.

14. Abe Y, Toyama K, Kazurayama M, Tanaka S, Yamaizumi $\mathrm{M}$, Ueno $\mathrm{M}$, et al. Low-normal platelets and decreasing platelets are risk factors for hearing impairment development. Laryngoscope 2021;131:E1287-E1295.

15. Gangopadhyay P, Prasad BK. A study of aetiological profile of unilateral sensorineural hearing loss. Bengal Journal of Otolaryngology and Head Neck Surgery 2019;27:19-28.

16. Mohammed SH, Shab-Bidar S, Abuzerr S, Habtewold TD, Alizadeh S, Djafarian K. Association of anemia with sensorineural hearing loss: A systematic review and metaanalysis. BMC Res Notes 2019;12:283.

17. Bing D, Wang DY, Lan L, Zhao LD, Yin ZF, Yu L, et al. Serum bilirubin level as a potential marker for the hearing outcome in severe-profound bilateral sudden deafness. Otol Neurotol 2019;40:728-35. 